\title{
Federico Cesi's Mycological Codex and its copies
}

\author{
Andrea Ubrizsy Savoia
}

Received: 22 March 2013/Accepted: 31 July 2013/Published online: 6 September 2013

(c) The Author(s) 2013. This article is published with open access at Springerlink.com

\begin{abstract}
According to documents of the time, Federico Cesi, founder of the Lincean Academy in 1603 [Editorial Note: "Accademia Nazionale dei Lincei" is the official name of this Academy, and its members are called "Lincei"], appears to have been the first to study mushrooms with scientific technology, even if no such publications on this topic have come down to us. In 1896, an anonymous mycological codex in two volumes preserved in the library of Kew Gardens (London) was attributed to Cesi, and considered the only derivative of his scientific work on the subject. Until recently, very little was known about the ground-breaking studies of fungi of this scientist. In 1980, the original mycological codex by Federico Cesi was identified, in three volumes, preserved in Paris, in the library of the Institut de France: this is a clear testimony of the first mycological observations made by Cesi through the microscope and of his intuition about the great diversity of fungi. Again, Cesi proves to have been a forerunner of the scientific development that took place in the later period of the Enlightenment. New evidence regarding the scientific influence of Cesi has now been found. Some mycological drawings by Bruno Tozzi (1656-1743), kept in the Bodleian Library in Oxford, when compared with both the similar drawings made by Tozzi and kept in the National Central Library of Florence and the Cesi originals
\end{abstract}

Contribution from the Working Group on Diversitas and Biodiversity, European Vegetation Survey, IAVS.

An earlier version of this paper was given at the workshop in Perugia to celebrate the 400th anniversary of the founding of the Accademia dei Lincei.

\footnotetext{
A. Ubrizsy Savoia $(\bowtie)$

Dipartimento Biologia Ambientale, Università di Roma

"La Sapienza", Rome, Italy

e-mail: savoia-ubrizsy@katamail.com
}

in Paris, are clearly shown to be copies of Cesi's mycological images. They give further confirmation of the correctness of the attribution of the codex in the library of Kew Gardens. There are suggestions in the modern literature on Cesi's mycological codex that Pier Antonio Micheli used Cesi's drawings, but this opinion cannot be confirmed.

Keywords History of mycology $\cdot$ Mycological codex · Federico Cesi · Bruno Tozzi · Bodleian Library Oxford - Kew botanic garden Library . Biblioteca Nazionale Centrale di Firenze .

Pier Antonio Micheli · Leone Strozzi

When Federico Cesi (1585-1630), founder of the Lincean Academy in 1603, began the study of fungi, knowledge in the field of mycology was still at a preliminary stage. The fungi were present in the majority of botanical works of the time, but only with a few notes about their culinary properties or toxicity, especially through citations from classical authors of antiquity. The brief comments were accompanied by inaccurate figures that barely resembled their models, for the most part also copied from previous works. The interest was mainly in edible mushrooms and a few others (mushrooms, lichens and algae) with medicinal and practical uses. The only exception is the Fungorum in Pannoniis observatorum Brevis Historia by the Flemish scholar Carolus Clusius (Charles de l'Ecluse, 1526-1609), a sort of monograph, published in 1601, on edible and poisonous fungi observed during the years 1579-1584 during a stay in the territory which formed ancient Pannonia. The text must have been accompanied by illustrations that Clusius prepared thanks to his Hungarian patron baron Batthyany and local experts, but the drawings were lost after the departure of Clusius. The collection of 
drawings, then known as the mycological Codex of Clusius, reappeared only in the middle of the seventeenth century (Istvànffi 1900; Ubrizsy Savoia 1983, 2007). Cesi had never seen or heard of the Codex of Clusius, but he knew the book published in 1601, of which he had a copy (Capecchi 1987). Expressions of appreciation for this work by the Linceans can be found in the Rerum Medicarum Novae Hispaniae Thesaurus of Francisco Hernández (1651, p. 537; Baldriga 2002, 2007). Also significant is Cesi's mention of the name of Clusius (one of the very few cases of quotation of contemporary authors) and the use of the figure published (in 1601) by Clusius of the fungus Clathrus ruber P. Micheli ex Pers. (= Clathrus cancellatus Tourn. ex Fr.) with the note "Ut in Clusio pingitur" in Cesi's own mycological codex (Library Institut de France, Paris, BIF, ms. 968, c. 108). It is well known that Clusius was one of the first foreign scholars to be contacted by the founders of the Lincean Academy for membership or at least for advice (Gabrieli 1989).

The Codex of Clusius was limited to edible or poisonous macrofungi and their morphological characteristics, with the intention of facilitating more certain identification. The Neapolitan scholar Giovanni Battista della Porta, one of the first members (since 1610) of Cesi's Academy, had made observations on the reproduction of these organisms which were considered not to have 'seeds', i.e. cryptogams, called "planta minus perfecta" by Cesi in his Tabulae Phytosophicae (published in full in 1651, although the first 12 "tabulae" were already in circulation around 1630, cf. Carutti 1878; Graniti 2006). In Phytognomonica (1588) and Villae (1583/1592), della Porta describes his experiment with the "black powder" (which was nothing but a cluster of mature spores) of field mushrooms, but despite this interest, the number of fungi species known to him was modest (Ubrizsy Savoia 1980b). The great Bolognese naturalist Ulisse Aldrovandi (1522-1605), whose membership of the Lincean Academy was requested as early as 1603, had an iconographic collection (now included in the Fondo Aldrovandi, ms. Drawings of flowers and fruits in ten volumes in the University Library of Bologna) with some mycological drawings which demonstrate his interest in the wide variety of fungi. Among them are some of the main species of edible and poisonous mushrooms then known as well as some species of small and practically useless fungi.

Seen in the light of this background, the contribution of Cesi to the study of fungi is a step that we can call decisive. His great merit in mycological matters has two aspects: the first is the use of the microscope (constructed by Galileo Galilei) for a better understanding of the morphology and in consequence the generation (reproduction) of these organisms; the second is the aim of describing as many of these organisms growing in a given territory as possible (what we now understand as the fungal flora of an area). This territory was, with few exceptions, his own land (in today's Umbria, Marche and Lazio, and possibly also in Tuscia as far as the Roman Campagna). For documentation and further comparisons, given the need to immediately illustrate mushrooms in their natural colours due to their changeable and impermanent characteristics, colourful designs were prepared of these fungi (some of them observed also under the "microscope") without distinction between useful and useless, rare and less rare species, though paying particular attention to curious, unusual shapes, sometimes with malformations of common species of fungi (on the 'wonderful' in Cesi see Olmi 1981 and Guerrini 2008).

There are very few traces of Cesi's mycological interest in the printed Lincean works and in his correspondence (Gabrieli 1996). Although self-taught and a botanist by vocation, Cesi certainly studied mushrooms, if not earlier, then at least from 1615, as demonstrated by the Erbario Miniato attributed to Cesi (Garbari and Tongiorgi Tomasi 2007) and by the letter of Teofilo Mueller of 16 March 1615 written to Cesi with reference to a fungus (Gabrieli 1996, Carteggio, no. 388). However, the observation of fungi with the aid of the microscope can be dated to the period 1625-1630, as it is assumed in the famous letter of Galileo Galilei to Cesi of September 1624 which accompanied this instrument of observation, then called "microscope" by the Lincean Johannes Faber (Johannes Schmidt, 1628). The date of 1624 seems to contradict the statement of Giovanni Bianchi (alias Jano Planco) in his Lynceorum Notitia (p. xxii), an introduction attached to the new edition of the Phytobasanos (1744) by the Lincean Fabio Colonna, indicating the year 1611: "Observavit in primis Caesius semina minutissima in Filicum genere, praesertim in Polypodio". According to Bianchi, Cesi used the microscope for observing fungi and later applied it to the observation of bees.

From references in Cesi's correspondence and a few later testimonies, we know of the existence of a mycological codex in three volumes based on Cesi's mycological studies which included drawings of high artistic quality and great precision. There must have been a text to accompany the codex, as according to Faber (in the zoological chapter of Rerum Medicarum Novae Hispaniae Thesaurus mentioned above p. 537) Cesi had written a book about imperfect plants that was to be published soon afterwards (Gabrieli 1989; Solinas 2000), but the work has not been found. Further evidence of the existence of an accompanying text is demonstrated by the following. Most of the sheets of the codex contain words by two different hands: a barely legible one pencilled in the top corner by Cesi himself (and perhaps even by Francesco Stelluti, one of the four founding members of the Accademia dei 
Lincei); and a clearly legible one in ink done by the copyist when the three volumes were already in the possession of the Lincean Cassiano dal Pozzo (1588-1657), i.e. after 1633. Those instances where the note written by the copyist is present while the original note by Cesi is missing indicate that the copyist (on whose identity see Solinas 2000) must have had a source written by Cesi at his disposal on which he could draw for his annotations on the sheet (as well as for the index).

In addition to this scant evidence, we have the joint testimony of the scholar Luigi Ferdinando Marsili (or Marsigli) from Bologna and of the chief physician of Pope Clement XI (Albani) and doctor at the Santo Spirito hospital in Rome Giovanni Maria Lancisi (1653-1720), both of whom claim to have seen the three volumes of mycological illustrations in the library of the Albani in Rome in their publication on mushrooms of 1714. These two scholars assigned the three volumes of the codex to Cesi and to Giovanni Ecchio (Joannes Eck, van Heeck; 1579-1620?), a Dutch physician from Deventer, one of the four founders of the Lincean Academy. The substantial collaboration of Ecchio, however, is not yet demonstrable: there are no references to this topic among his printed works, while very simple or even rudimentary drawings of some mushrooms in his surviving manuscripts have nothing in common with the mycological codex, which is now regarded as conceived by Cesi alone.

The testimony of Marsili and Lancisi prompted Gabrieli (1938), the tireless researcher on the history of the Linceans, to try to find the mycological work by Cesi. When in 1896 an anonymous collection of mycological drawings in two volumes was reported to be in the library of Kew Gardens in London, Saccardo (1895) believed them to be part of Cesi's original three-volume work, assuming that a few post-1630 additions (dated to 1680 and 1699) had been made by Lancisi or by the Bolognese botanist Giovanni Battista Trionfetti (or Triumfetti, 1678-1708). Trionfetti, who was already master of Marsili in his studies and mycological drawings (mostly still unpublished at the University Library of Bologna, Govi 1984) was the successor to the Lincean Faber in the chair of botany and director of the Botanical Garden at the Sapienza University in Rome and then entered into the favour of Pope Clement XI (Albani). The printed works of Trionfetti contain no references to the mycological volumes or much less to Cesi, having praise only for Marcello Malpighi (1628-94), improperly called a Lincean by Trionfetti. Solinas (2000, p. 96) though without any verifiable documentation to support his assertion, but probably following the opinion of Saccardo (though without quoting this source), assigns the two volumes in Kew Gardens (that bear the Strozzi coat of arms) to Lancisi and supposes that Lancisi (and Marsili) had seen them (bound in three volumes) and had them copied in the library of Leone Strozzi (1657-1722, also known for his rich museum in Rome). The documents now accessible in the Lancisi archive (Lancisiana Library, Rome) do not contain any reference to the relationship Strozzi-Lancisi except one letter in the Lancisi Epistolario (MM Lancisi, vol. 309, c. 58) written by Leone Strozzi on 9th November 1719, but it does not contain any material that might support the statement of Solinas. The derivation of the volumes in Kew from the Cesi codex was discussed by Ainsworth and Ubrizsy Savoia (1981). Today it is generally accepted that it was Bruno Tozzi (a monk in Vallombrosa Abbey towards the end of the seventeenth century), whose contact with Strozzi, unlike the supposed contact between Lancisi and Strozzi, is demonstrable (Mazzucotelli, pers. com., 2005), who copied the Cesi codex.

In contrast to Saccardo, Gabrieli (1928, 1929, 1938) argued that the two volumes recorded in 1896 by the Bulletin of Kew Gardens were only partial copies containing later (post-1630) additions; after leaving the Strozzi library they passed to the Sforza family, who sold the two volumes to the library of the Botanical Gardens at Kew in 1845. Gabrieli therefore continued to search for the three original volumes, but without success.

I was fortunate enough to discover and identify the original work of Cesi in 1978-79, in Paris, in the Library of the Institut de France (listed as Fungorum genera et species vol. I-III, MS 968-970) and to discover its history (Ubrizsy /Savoia/ 1980a). The three volumes were confiscated in 1798 as spoils of war by Napoleon's troops, along with other goods from the Albani family, and then taken to Paris, where later Baron Benjamin Delessert (1773-1847), a wealthy banker and distinguished botanist, came into their possession. Delessert, who had published the Icones plantarum Selectae of A.P. de Candolle in 1820-46, bought the herbaria of such famous botanists as Lemonnier, Ventenat, Burman as well as one of Linnaeus. His library as well as the collection of herbaria was open to a select public and was frequented by several important botanists such as A. de Jussieu, J. Decaisne, A.Th. Brongniart and G.A. Pritzel, author of Thesaurus (1847), a fundamental botanical compilation that also quoted unpublished and anonymous works. The curator of the herbarium and library was Antoine Lasègue (elected to the Royal Academy of Turin in 1847 on the proposal of J.H. Moris and V. Cesati, and president of the French Botanical Society in 1869). After the death of Delessert his heirs offered the library, including the herbals and the Cesi codex, to the Bibliothèque de l'Institut de France in Paris in 1869. Although the library of Delessert was frequented by several important scholars, at least between 1829 (the date of entry noted on the Cesi codex) and 1869, this codex did not attract the attention of any of them. There was some vague 
mention of the codex just a few decades before the Napoleonic despoliation. An example is the French mycologist Paulet (1793, I, p. 213) who added a few more notes to the three volumes of the Albani Library and, before him, the famous naturalist and priest Paolo Boccone (1633-1704), who claimed to have seen the mycological codex (from the Albani Library together with the three volumes of Cesi codex, as well as a herbarium made by Boccone in 1674, which was stolen during the occupation of Rome and subsequently also conveyed to the Bibliothèque de l'Institut de France in Paris).

The mycological codex in three volumes without a title and author's name lay forgotten and almost hidden in the personal library of the patron of botany Delessert in Paris, where only a few scholars had the opportunity to consult it, until its rediscovery and attribution (Ubrizsy /Savoia/ 1980a, 1999). The drawings of the Cesi codex were first published in 2005 by Pegler and Freedberg (Pegler and Freedberg 2005) (and presented to the public only in June 2006 in London: Clayton 2006; Harris 2006) and were therefore not available at the time of the presentation of this study at the international conference Diversitas and Biodiversity: searching the origins of a myth of the twentyfirst century, Perugia, 17th and 18th March 2006, organised by the Academy of the Lincei, National Committee for the Fourth Centenary of the founding of the Academy of the Lincei.

After the death of Cesi in 1630, the memory of this codex was lost. Even in the rare praise of Cesi's activity, only his printed works were remembered. A good example is the De Florum Cultura (Ferrari 1633, p. 15) by Giovanni Battista Ferrari (1583-1655), one of the first publications to contain an image of a plant observed under the microscope: it mentions only the Tabulae Phytosophicae (1630). Even John Ray, who in the introductory part of his Historia plantarum (1686-1704, vol. I. p. 13) dealing with ferns recalls the testimony of Fabio Colonna regarding Cesi and his microscopic study of plants, fails to mention Cesi by name in the chapter on mushrooms (only the Lincean Fabio Colonna, 1567-1640, is mentioned in connection with the "Fungus coralloides" vol. I. p. 103, which is the aforementioned Clathrus ruber P. Micheli ex Pers.)

In the introduction to his Fungorum agri Ariminensis historia (1755) on fungi found in the vicinity of Rimini, Giovanni Antonio Battarra (1714-1789) had mentioned three mycological codices which were still unpublished at the time: that of Cesi, citing the testimony of Lancisi and Marsili; the drawings of mushrooms observed in Hungary by the same Marsili (reported in 1699-1700); and that of monk Bruno Tozzi in Vallombrosa Abbey. The author does not say whether he had been able to see the first two codices, but he does affirms (in the same introduction to the book) that in 1740 he was able to study the coloured drawings of Sylva Fungorum by Father Bruno Tozzi at the Abbey of Vallombrosa. In his introduction, Battarra tells how his passion for the study of fungi arose under the influence of the aforementioned Giovanni Bianco, a doctor and natural scientist in Rimini (where Federico Cesi's brother Angelo was bishop from 1627 to 1646, as Bianco recalled; Montanari 2001), where he had reorganised the Academy of the Lincei of which Battarra was an elected member. Thanks to Battarra, the names of Cesi and Tozzi appeared together for the first time in a printed work, but without any connection being made between them. These two names are, however, closely related, as becomes evident from a comparison of Cesi's mycological codex in Paris with a collection of mycological drawings by Tozzi in the Bodleian Library in Oxford.

These coloured drawings by Tozzi are included in manuscript collections MS Sherard 192 and 197-197a in Oxford and contain numerous drawings copied from the Cesi mycological codex now in Paris. The evidence for this derivation, besides a visual comparison, is provided by the fact that the index to the Tozzi mycological drawings contains 67 items which occur in exactly the same form in the index of the Cesi codex; moreover, the note "Ex codici Caesiis" is often repeated. Therefore Tozzi was aware that he was copying from a codex which at the time was known to be by Cesi. MS Sherard 192 contains relatively few figures and notes or information about Tozzi's copying from the Cesi codex such as "Ex Cod. Caes.".

The second step was the comparison of the figures in Tozzi's Sylva Fungorum in Oxford (MS Sherard 197-197a) that were copied from the Cesi codex with the pictures of mushrooms in the unpublished Florentine codex Sylva Fungorum (specifically the first part up to page 427), also by Tozzi, and now in the National Central Library of Florence (BNCF CSAV 1097). It was expected that these figures of fungi would be identical as they were copied in the same way. But the positions of the single figures on the sheets have been modified (perhaps to follow the classification proposed by Micheli?), changed with respect to the original and in a different way in each of Tozzi's two manuscripts. It is remarkable that the images of mushrooms seen under a microscope by Cesi are missing in both of Tozzi's Sylvae.

Further confirmation of the consultation by Tozzi of the Cesi codex (or its copy) is provided by an index found among the Tozzi manuscripts in Florence (BNCF CS, G.IX.1099). This index could be part of his Sylva Fungorum, as the entries show a remarkable convergence with the captions and indices of the Cesi codex in Paris, with the Sylva Fungorum in Oxford, and also with the two volumes from the Strozzi library now at Kew. Tozzi's Florentine manuscript (BNCF CS, G.IX.1099 cc. 91-92) is also important as it contains the index of Book II of the Cesi 
codex in a version in which the sequence of the individual names of mushrooms does not coincide with the sequence we find (today) in the corresponding Paris volume. It is thus a 'free' transcription by Tozzi, but it should be noted that this index is not present in the Kew volumes. The author of this index has therefore personally consulted the Cesi codex (or an as yet unknown copy of this which must, however, be different from the Kew volumes).

The third comparison concerns the figures of the Cesi codex, the images copied from this in the two Sylva Fungorum volumes by Tozzi, and the images of the two-volume Icones Fungorum ineditorum at Kew by an anonymous author but clearly derived from the Cesi codex. Comparison reveals that they are identical but for a few exceptions (Ubrizsy Savoia 2006). These exceptions relate to the absence of certain drawings of mushrooms (especially those seen under the microscope) in the two volumes of Kew, a significant finding which lends support to the view of some scholars regarding the existence of a third volume (although not a bulky one) in addition to the current two volumes. The single mushroom figures of the Cesi codex have been rendered more compact by removing the blank spaces on the sheets in the original. As the Kew volume lacks 136 of the figures contained in the Cesi codex, the hypothetical third volume would have contained pages with only a single drawing per page. Given the concentrated positioning of the figures on the sheets (far more images on each page than in Cesi's original) adopted by Tozzi, there may not have been a third volume at all. The accuracy of the images shows a greater proximity between the volumes of Paris and Kew, than with the Florentine and Oxford Sylva Fungorum, while the latter two are very similar to one another in this respect.

In the history of mycology, based on Tozzi's persistent claim (Prampolini 1991) that his designs were original and the result of direct mycological observation, this connection and this copying had never been suspected. Apart from the notes in the Oxford Sylva Fungorum mentioned above, Tozzi had never made any reference to the figure of Cesi or his codex. There are other notes in this Oxford manuscript: the introduction (reported by Ramsbottom BLO in Ms Sherard 197a, p. 27) shows that many fungi contained in the Sylva were designed on the basis of specimens collected by Tozzi ("collegimus propriis") in their place of origin, while many others were copied from the three volumes of the Cesi codex which could be seen in Rome in the Library of Prince Leone Strozzi ("multos deproprimus ex tribus Codicibus Caesiis qui Romae osserverantur [sic] in Bibliotheca Lyonei Principis Strozzi, speciale tanti vivi favore"), while yet other drawings were received from friends, especially from Micheli ("plurimos etiam ab amicis accepimus praecipue a D. Micheli supra volumen nostrum eravit in Sylvam ad divinum magnificum supremi humanis excellentiam"). The sequence of fungi present in the volume by Tozzi follows the classification introduced by Micheli ("Micheliana perfecta methodus"). So Tozzi had come into contact with the Cesi codex (probably not the original but a copy) in the Strozzi Library in Rome.

The 1748 inventory of the possessions of Maria Teresa Strozzi, heiress to the prelate (Guerrieri Borsoi 2004) mentions "Tre tomi grandi nei quali si contengono diverse specie di fonghi" (Three large volumes which contain different species of fungi) with, among others, five volumes that had the title "Bottanica". This note tempts one to think immediately of the three large volumes of mushrooms by Cesi (now in Paris), especially if we remember that the number of volumes of Cesi's plant codex Plantae et Flores (also in Paris, with a binding attesting the same provenance from the Albani library) is five (Ubrizsy /Savoia/ 1980a)! On the other hand, we should consider that Strozzi's rich library (which he began in the 1680s) included the collection of Francesco Corvino (1605-1679), which already contained material of his father, the pharmacist Enrico Corvino (the Italianized name of Hendrik De Raef from Delft, who died in Rome in 1639), who had accompanied Cesi on many botanical excursions. Francesco Corvino devoted himself to botanical studies too and was a friend of Cassiano dal Pozzo. Among the items from the Corvino collection that went to the Strozzi library were some seven volumes of botanical drawings, executed probably by Corvino senior himself (Guerrieri Borsoi 2004).

We can now ask whether Pier Antonio Micheli had come across the three mycological volumes in the library of Leone Strozzi and had taken advantage of the mycological drawings of the Cesi codex. In a letter from Carlo Tommaso Strozzi (ASF, CS, III, LXIII/II, c. 54; Guerrieri Borsoi 2004) written in Florence to his uncle Monsignor Strozzi, the writer recalls having heard from Micheli that the latter had copied many fungi, of which he did not have any other image, from the "three volumes" of Leone Strozzi (probably in the period 1720-1722). This short passage has been enough for some to say that Micheli had copied from Cesi! Guerrieri Borsoi (2004) is more cautious and writes, "Micheli repeatedly visited the museum of Strozzi and some figures of his book of 1729 are derived from drawings or specimens seen in the collection Strozzi, but more detailed data are lacking." If we examine Micheli's Nova Plantarum Genera (1729), we find that the name of Cesi is totally absent, that there is no reference to people (such as Faber or Stelluti as Cesi's collaborators, or Tozzi as copyist) connected with the Cesi codex, and that there no references to anonymous mycological works. Micheli lists very precisely the printed sources and the unpublished manuscripts. The latter do not include Tozzi's Sylva Fungorum, much less any name that could refer to the collection of Cesi drawings. Micheli could easily have 
heard about these drawings and their author not only from Tozzi, his mentor, but also from the aforementioned Giovanni Bianchi from Rimini (then chief papal physician), whose friendship with Micheli dated from 1727 (BNCF, Targioni $135 \mathrm{~ms}$, c. 166).

From a first comparison of the mycological drawings preserved among the unpublished manuscripts of Micheli (Library of Botany, University of Florence) with the figures in the Cesi codex, there does not appear to be any dependence. None of the figures in his Nova Plantarum Genera is copied from Cesi, unlike the case of Tozzi, and the vague similarities can simply be interpreted as representing the 'conventional' form of some species of fungi, as if Micheli was following a graphic model for these species and not an exact copy of the specimen. The figure of the already mentioned Clathrus ruber Mich.: Pers. (the generic name was given by Micheli!) in plate 93 of the Nova Plantarum Genera is quite similar, but not the exact copy of the fungus called "Conceptus" in volume I. c. 107 of the Cesi codex in Paris (BIF, Ms 968); the figure is also found in Volume II. f. 36 of Kew. We may add that the other Clathrus figure in the Cesi codex (Ms 968 folio 108), taken from Clusius' 1601 publication and copied into Volume II. f. 37 of Kew, also occurs in the Florence Sylva Fungorum (BNCF, CS, AV1097 c. 245) together with another image of this fungus. The latter image is located in Volume II. f. 38a Kew, but is lacking in the original volumes of the Cesi codex in Paris!

The presence of a single, fortuitous case of a vague similarity between a drawing in the Cesi codex and one in the work by Micheli cannot be considered confirmation of the statement that Micheli had copied from the Cesi codex. Micheli's book does not contain a single name used by Cesi for its mushrooms. The spirit that permeates the Cesi codex, namely the desire to present the wide variety of mushrooms-including microfungi hitherto little considered and less studied-from a particular territory, a first step towards the modern concept of biodiversity, emerges only marginally in Micheli and not as a clear derivation, nor does Micheli state that he feels it to be something that he has borrowed from Cesi or his codex.

The correspondence between the English diplomat and botanist William Sherard and Micheli (Ottaviani 2000) reveals how Sherard had sent original mycological drawings by the botanists Johann Jacob Dillen and Johann Philipp Breyn to Florence, after his departure from this city where he had met Micheli. They were to be copied (by Micheli, or rather, by his employees, or by Tozzi) and then the originals were to be returned with the copies (copies of drawings by Dillen and Breyn in the legacy of Tozzi suggest that second, personal copies were also made as well as those sent to London).

There are figures in Micheli's book that are identical in every detail to those in the Sylva Fungorum of Tozzi, but these are copied not from Cesi but from other authors (such as Dillen, Breyn, Boccone, etc.). We have identified these same figures among the mycological drawings in Micheli's archive of manuscripts, among the non-autograph volumes (Ragazzini 1993), especially ms. 55 and ms. 66 in Florence (BdBFI, Fondo Micheli). References to the "Lib.(ro) Strozio" and "Sig.re Carlo Strozzi" that recur in the manuscript volumes of Micheli (BdBFI, ms Micheli, especially in ms. 52) are probably related to the aforementioned Carlo Tommaso, who corresponded with Leone Strozzi on subjects of natural scientific interest, as Carlo Tommaso was a member of the Florentine Society of Botany (ASF CS III, LXIII/II).

Having demonstrated the unsustainability of such journalistic generalisations as ("All later mycologists were profoundly influenced by the work by Micheli, and therefore indirectly by the Cesi drawings"), we can return to a comparison of the four codices, viz. the original in Paris, the two-volume copy in Kew, and the two Sylvae Fungorum by Tozzi in Oxford and Florence, respectively. This comparison throws new light on the history of the Cesi codex, as well as enabling a reappraisal of the reliability of the relationship between the original in Paris and the copy at Kew, which has already been the object of a series of studies with contrasting hypotheses, interpretations and attributions, a confusion compounded by the fact that these volumes lack a frontispiece, title or indication of author.

The original Cesi codex entered the library of the Lincean Cassiano dal Pozzo through the purchase of the collections left by Prince Cesi in 1633 (Gabrieli 1928), where it remained until the sale to (the keeper of) the Vatican Apostolic Library in 1702-03 (Graniti 2006). From there it passed into the Albani library (first into the private library of Pope Clement XI Albani, who later passed the books on to his nephew Cardinal Alessandro Albani in 1714), then travelled to Paris (BIF, as we have seen), while the (partial) copy today in Kew passed from the Strozzi library to that of the Sforza in 1826 before arriving in England in 1845. According to the prevailing opinion, the two volumes in Kew were copied by Tozzi (the calligraphy of the copies of the Sylva Fungorum in Oxford and Florence is identical and also seems to correspond to that of the Kew volumes). Tozzi, however, always mentioned the Strozzi library volumes in a neutral, detached manner in his manuscript without alluding to his involvement as the copyist of these volumes (now in Kew). As we have seen, the Strozzi library included material from Corvino senior and junior, including seven volumes of botanical drawings, executed probably by Corvino senior himself (Guerrieri Borsoi 2004). Further uncertainty arises from the fact that both copies of the Sylva Fungorum (Oxford and Florence) include drawings copied from the Cesi codex which, however, are lacking in the Kew volumes. 
All these differences do not help to clarify the identity of the 'three' mycological volumes from the Strozzi library and give rise to at least three hypotheses. Were they the originals by Cesi that passed in those years into the Strozzi library? (To assume a direct contact between the Strozzi library and the Cesi family, we must remember that Federico Cesi was connected with the Strozzi, as Maddalena Strozzi was the mother of Isabella Salviati, who married Cesi in 1617 and survived him as his widow.)

Or were copies made by Tozzi which are today in Kew (in only two volumes)? The third hypothesis is that they were copies made from the original by Cesi prior to Tozzi's consultation of them. We do not have the elements required for a convincing answer.

To conclude, we recall that in the sixteenth and seventeenth centuries the distribution of scientific works (especially unpublished manuscripts and drawings) occurred by means of epistolary contact through the 'Res publica Literaria'. Copies were repeatedly made by scholars as well as by amateurs and collectors. This is what happened, although to a limited extent, in the case of the mycological codex of Cesi. Believed to be lost for a very long time, despite its vicissitudes, this three-volume codex has had its users; but they are very few, and not all those whose names have circulated in recent publications were among them.

Open Access This article is distributed under the terms of the Creative Commons Attribution License which permits any use, distribution, and reproduction in any medium, provided the original author(s) and the source are credited.

\section{References}

Ainsworth GC, Ubrizsy Savoia A (1981) The first microscopic observations relating to the natural history of fungi. Kew, Rome, p 11 [figs 2 (unpublished manuscript)]

Baldriga I (2002) L'occhio della lince: i primi lincei tra arte, scienza e collezionismo: (1603-1630). Accademia Nazionale dei Lincei, Roma

Baldriga I (2007) The influence of Clusius in Italy. In: Egmond F, Hoftijzer P, Visser R (eds) Carolus Clusius-towards a cultural history of a Renaissance naturalist. Federico Cesi and the Accademia dei Lincei, Amsterdam, pp 249-265

Capecchi A (1987) Per la ricostruzione di una biblioteca di Federico Cesi Lynceorum princeps. Rend fis Acc Lincei. XLI 5-6:145-164

Carutti D (1878) Degli ultimi tempi, dell'ultima opera degli antichi Lincei e del risorgimento dell'Accademia. Atti mor Acc Lincei II: $182-251$

Clayton M (2006) Three newly published albums of seventeenthcentury mycological drawings. Mycologist 20(4):163-169

Colonna F (1744) Phytobasanos: cui accessit vita Fabii et Lynceorum notitia adnotationesque in Phytobasanon, Iano Planco Ariminensi auctore, 2nd edn. P.C. Viviani, Florence

Faber J (1628) Animalia Mexicana Descriptionibus. Romae apud I. Mascardum

Ferrari GB (1633) De Florum cultura libri IV. Romae, exc. S. Paulinus
Gabrieli G (1928) Alla ricerca di alcuni Cimelii Lincei. Arch. stor. di Scienza IX:225-242

Gabrieli G (1929) Due codici iconografici di piante miniate nella Biblioteca Reale di Windsor. A proposito di Cimeli Lincei. Rend fis Acc Lincei 10:531-538

Gabrieli G (1938a) Cimelii di scienza Lincei ritrovati. Rend fis Acc Lincei XXVII:693-704

Gabrieli G (1938-1942) Il Carteggio linceo della Vecchia Accademia di Federico Cesi (1603-1630). Roma (reprint 1996)

Gabrieli G (1989) Contributi alla storia dell'Accademia dei Lincei. Acc Lincei, Roma

Garbari F, Tongiorgi Tomasi L (2007) Flora : the Erbario Miniato and other drawings. The Paper Museum of Cassiano dal Pozzo. Royal Collection Enterprises, London

Govi G (1984) Luigi Ferdinando Marsili micologo bolognese (1658-1730). Clueb, Bologna

Graniti A (2006) Il mondo vegetale nella visione di Federico Cesi. In: Graniti A (ed) Federico Cesi, un principe naturalista. Acc Lincei, Roma, pp 17-99

Guerrieri Borsoi MB (2004) Gli Strozzi a Roma. Mecenati e collezionisti nel Sei e Settecento. Fondazione Marco Besso, Roma

Guerrini L (2008) Nuovi saperi e antichi primati. Studi sulla cultura del primo Seicento. Bononia University Press, Bologna

Harris SA (2006) The Paper Museum of Cassiano dal Pozzo. Series B: Natural History. Fungi. J History Collect 18:2

Istvànffi GY (1900) Études et commentaires sur le Code de l'Escluse augmentés de quelques notices biographiques. chez l'Auteur, Budapest

Montanari A 2001 (2004)—Tra erudizione e nuova Scienza. I Lincei riminesi di Giovanni Bianchi (1745). Studi Romagnoli LII, pp 401-492

Olmi G (1981) In essercitio universale di contemplatione et prattica: Federico Cesi e i Lincei. In: Boehm L, Raimondi E (eds) Università, Accademie e Società scientifiche in Italia e in Germania dal Cinquecento al Settecento, Bologna, pp 169-235

Ottaviani A (2000) La periferia inquieta del vivente: il dibattito sulla generazione delle piante imperfette fra Sei e Settecento e l'opera botanica di Pier Antonio Micheli. Dottorato di ricerca in filosofia e storia delle idee Università degli studi di Catania, Facoltà di lettere e filosofia 11. ciclo, Catania

Paulet JJ (1793) Traité des Champignons. Impr. nationale, exéc. du Louvre, Paris

Pegler D, Freedberg D (2005) Fungi. The Paper Museum of Cassiano dal Pozzo. A Catalogue Raisonné. Drawings and Prints in the Royal Library at Windsor Castle, the British Museum, the Institut de France and other Collections. Series B. Natural History. London

Prampolini S (1991) L'immagine naturalistica nell'abbazia di Vallombrosa fra XVII e XVIII secolo. Tesi di laurea, anno accademico 1990-1991. Arezzo

Ragazzini S (ed) (1993) I manoscritti di Pier Antonio Micheli conservati nella Biblioteca botanica dell'Università di Firenze. Inventari e cataloghi toscani, 43, Giunta regionale toscana, Firenze

Saccardo PA (1895) La Botanica in Italia. rist. anast. Forni edit., Venezia

Solinas F (2000) Le "Naturali Esperienze". In: Solinas F (ed) I segreti di un Collezionista. Le straordinarie raccolte di Cassiano dal Pozzo 1588-1657. Ed. De Luca, Roma, pp 91-120

Ubrizsy /Savoia/ A (1980a) Il codice micologico di Federico Cesi. Rend fis Acc Lincei 68:129-138

Ubrizsy Savoia A (1980b) Erste unmittelbare Erkenntnisse bezueglich der Existenz der Sporen. Schweizerische Zeitschrift fuer Pilzkunde (Bern) 115(4):54-59 
Ubrizsy Savoia A (1983) Wissenschaftliche Beziehungen zu Italien. Der Maler der Pilzaquarelle im Clusius-Codex. In: Aumüller A, Jeanplong $\mathrm{J}$ (eds) Clusius, Carolus: Fungorum in Pannoniis observatorum brevis historia et Codex Clusii. Mit Beitraegen von einer internationalen Autorengemeinschaft. Budapest Akadémiai Kiadó, Graz: Akademische Druck- u, Verlags, pp 54-56

Ubrizsy Savoia A (1999) Mycological illustration from Dioskorides onward, with special reference to Italian contributions. In: Onofri S, Graniti A, Zucconi L (eds) Italians in the History of Mycology. N.Y. Mycotaxon Ltd, Ithaca, pp 15-55

Ubrizsy Savoia A (2006) Relationship between Libri Picturati A. 16-30 and printed Renaissance botanical works; some new data on 'Clusius Codex' and the mycological 'Cesi Codex'. 2nd International Conference of the European Society for the History of Science "The History of Science and the Cultural Integration of Europe", Cracow. http://www.2iceshs.cyfronet.pl/2ICESHS_ Proceedings/Chapter_20/R-12_Ubrizsy.pdf. Accessed Sept 6-9 2006

Ubrizsy Savoia A (2007) Some aspects of Clusius' Hungarian and Italian relations. In: Egmond F, Hoftijzer P, Visser R (eds) Carolus Clusius-Towards a cultural history of a Renaissance naturalist. Edita KNAW, Amsterdam, pp 267-292 